\title{
Effect of addition of sweet potato on physiochemical properties of Kochujang
}

\author{
Su-Ah Park, Dong-Han Kim * \\ Department of Food and Nutrition, Mokpo National University, Muan 58554, Korea
}

고구마를 이용한 고추장의 숙성 중 이화학적 특성 변화

\author{
박수아 · 김동한 * \\ 목포대학교 식품영양학과
}

\begin{abstract}
Kochujang was prepared by replacement of rice ( $25 \%$, control) with pumpkin or purple sweet potato by 0.5 , 10 , and $15 \%$ (total addition ratio of rice and sweet potato $=25 \%$ of sample). Effects of the addition of sweet potato on physiochemical properties of fermented Kochujang were investigated. Viable cells of yeast decreased in the sweet potato-added Kochujang at the later stage of fermentation, while there was no significant difference in the number of bacteria among the test groups. As the addition ratio sweet potato increased, a-amylase activity increased while protease activity decreased. Hunter $\mathrm{L}$, a, and b values of Kochujang prepared with purple sweet potato were lower than those with pumpkin sweet potato. Changes in $\Delta \mathbf{E}$ value was greater in Kochujang prepared with pumpkin sweet potato than that with purple sweet potato. Oxidation-reduction potential and water activity were higher in sweet potato-Kochujang than control, but reducing sugar content was higher in control. Alcohol and amino-type nitrogen contents were higher in Kochujang prepared with pumpkin sweet potato than that with purple sweet potato, but it was not significant. Overall sensory acceptability was highest in Kochujang prepared with $10 \%$ of purple sweet potato while that with $15 \%$ pumpkin sweet potato was the least preferred.
\end{abstract}

Key words : Kochujang, sweet potato, physiochemical property

\section{서 론}

고추장은 전분질과 고춧가루, 메주, 소금 등을 주원료로 하여 제조되는 우리나라 고유의 전통발효식품(1)으로 매운 맛과 단맛, 구수한 맛이 조화를 이루어 독특한 풍미와 기호 성을 가진다. 고추장의 숙성은 메주 또는 koji(2)에서 유래하 는 가수분해효소와 효모, 세균의 발효작용으로 진행되며, 원료의 종류와 배합비율 $(3,4)$ 에 따라 품질특성에 차이가 난다. 고추장은 발효과정에서 미생물의 증식에 의해 품질 이 좌우되기 때문에 마늘과 양파(5), 겨자와 고추냉이(6),

*Corresponding author. E-mail : dhankim@mokpo.ac.kr Phone : 82-61-450-2524, Fax : 82-61-450-2529

Received 8 April 2016; Revised 13 May 2016; Accepted 16 May 2016.

Copyright (c) The Korean Society of Food Preservation. All rights reserved.
강황(7) 등을 부원료로 이용하여 미생물의 생육에 의한 숙 성을 조절하기도 한다. 전통식고추장은 전분질로 찹쌀(8) 을 주로 이용하나 멥쌀이나 잡곡류(9,10), 감자(11) 등이 이용되기도 한다. 또한 고추장의 풍미향상을 위하여 전분 질원의 일부를 감귤(12)이나 호박(13), 사과(14) 등으로 대 체한 연구가 보고 된바 있다. 최근에는 건강을 추구하는 소비자의 취향에 따라 고추장에도 기능성 향상을 위해서 버섯(15)과 다시마(16) 등 기능성 소제의 첨가가 시도되었다.

한편 고구마는 메꽃과의 다년생 식물로 단위 면적당 수 확량이 많으며 최근에 건강식으로 많이 이용되고 있다(17). 고구마의 기능성은 비타민 $\mathrm{A}$ 와 $\mathrm{E}$ 의 항암-항산화 작용, 식 이섬유의 변비해소, 칼륨과 칼슘의 혈압강하와 출혈방지, 안토시아닌 색소의 간 보호 작용 등이 알려져 있다(18). 현재 고구마는 생식 이외에 웰빙을 표방하는 소비자들의 다양한 요구로 발효주와 묵, 면류, 당면, 음료, 제과 - 제빵, 떡, 양갱, 요구르트 등 식품가공의 소재로 이용이 넓혀지고 
있다(19).

이에 본 연구에서는 고추장 제조시 전분질원으로 멥쌀의 일부를 고구마로 대체하여 그 첨가비율을 달리하여 혼합하 고 고구마가 고추장의 발효 및 숙성에 미치는 이화학적 특성을 비교 검토하였다.

\section{재료 및 방법}

\section{재 료}

고추장 제조에 사용한 멥쌀과 고춧가루, 엿기름, 소금(천 일염, $\mathrm{NaCl} 80 \%$ 이상, 청정원)은 시중 마트에서 구입하였으 며, 알코올은 무수알코올(99.8\%, Baker, Deventer, Netherlands) 을 사용하였다. 고구마는 전남 무안군 현경면에서 재배한 자색고구마(품종명: 신자미)와 호박고구마(품종명: 연황 미)를 이용하였고, $k o j i$ 는 토박이순창식품(주)에서 제조한 밀가루 koji(Aspergillus oryzae)와 대두 koji(Bacillus subtilis) 를 이용하였다.

\section{고추장}

고추장 담금은 멥쌀가루의 배합비율을 $25 \%$ (대조구)에 서 $20,15,10 \%$ 로 줄이고 엿기름과 물을 첨가하여 가열 호화시킨 후 증숙한 자색고구마와 호박고구마를 $5,10,15 \%$ 되게 첨가하였다. 나머지 원료는 Table 1 과 같이 소맥분 $k o j i$ 와 대두 $k o j i$ 를 각각 $5 \%$ 혼합하고, 고춧가루 $12 \%$, 소금 $9 \%$, 알코올 $2 \%$ 를 첨가하여 고추장을 제조하고 $5 \mathrm{~L}$ 의 플라 스틱 용기에 담아 항온기에서 $20^{\circ} \mathrm{C}$ 로 12 주간 숙성시켰다.

\section{생균수와 효소활성도}

고추장의 호기성 세균수는 tryptic soy agar, 통성혐기성 세균은 APT agar를 이용하여 평판도말한 후 $1.5 \%$ agar를 덮어 중층배양 하였고, 효모수는 rose bengal agar 배지를
수하였다(4). 효소액은 고추장 $5 \mathrm{~g}$ 을 증류수로 희석하여 100 사용하여 평판도말법으로 $30^{\circ} \mathrm{C}$ 에서 1 3일간 배양한 후 계 $\mathrm{mL}$ 로 정용하고 실온에서 2시간 진탕 추출한 후 동양여지 No. 2 로 여과한 것을 조효소액으로 하였다. 효소활성도는 a-amylase의 경우 blue value 변법(20)에 준하여 측정한 후 활성도는 반응 10 분 전후의 흡광도 차이에 희석배수를 곱하여 표시하였고, $\beta$-amylase는 Fuwa의 방법(20)에 준하 여 고추장 $1 \mathrm{~g}$ 에서 1 시간 반응 후 생성되는 환원당량을 DNS법으로 정량하여 glucose 양( $(\mathrm{MM})$ 으로 활성도를 비교하 였다. 단백질 분해력은 Anson의 방법(21)에 준하여 $\mathrm{pH} 3.0$, 6.0(편의상 산성, 중성 protease로 함)으로 구별하여 측정한 후 고추장 $1 \mathrm{~g}$ 에서 30 분에 생성하는 tyrosine 양 $(\mu \mathrm{M})$ 으로 활성도를 나타냈다.

\section{일반성분}

고추장의 일반성분은 기준미증분석법(22)에 준하여 $\mathrm{pH}$, 적정산도, 환원당, 알코올, 아미노산성 질소, 암모니아성 질소를 정량하였다. 색도는 색차계(Chromameter CR-200, Minolta, Osaka, Japan)로 측정하여 Hunter scale에 의해 L(lightness), a(redness), $\quad b$ (yellowness) 값과 total color difference인 $\Delta \mathrm{E}=\left[\left(\mathrm{L}_{0}-\mathrm{L}_{1}\right)^{2}+\left(\mathrm{a}_{0}-\mathrm{a}_{1}\right)^{2}+\left(\mathrm{b}_{0}-\mathrm{b}_{1}\right)^{2}\right]^{1 / 2}$ 값으로, 산화 환원전위는 ORP-meter(Orion525A+, Beverly, MA, USA)를 이용하여, 수분활성도는 Novasina LabSwift-Aw(CH- 8853, Novasina AG, Lachen, Switzerland)를 사용하여 측정하였다.

\section{관능검사}

12 주간 숙성시킨 고추장에 대하여 20 명의 식품영양학과 학생들을 대상으로 맛과 향기, 색, 종합적인 기호도 4가지 항목을 7단계 평점하게 하여 SPSS/PC package 12.0(SPSS Inc., Chicago, IL, USA)을 사용하여 분산분석을 하고 Duncan's multiple range test에 의해 통계 처리하였다.

Table 1. The mixing ratio of raw materials for the preparation of Kochujang

(unit: \%)

\begin{tabular}{ccccccccccc}
\hline \multirow{2}{*}{ Kochujang $^{1}$} & \multicolumn{10}{c}{ Raw material } \\
\cline { 2 - 10 } & Non glu- tinous rice & Sweet potato & Red pepper & Wheat koji & Soybean koji & Malt & NaCl & Ethanol & Water \\
\hline Control & 25 & 0 & 12 & 5 & 5 & 0.4 & 9 & 2 & 41.6 \\
SJM-5 & 20 & 5 & 12 & 5 & 5 & 0.4 & 9 & 2 & 41.6 \\
SJM-10 & 15 & 10 & 12 & 5 & 5 & 0.4 & 9 & 2 & 41.6 \\
SJM-15 & 10 & 15 & 12 & 5 & 5 & 0.4 & 9 & 2 & 41.6 \\
YWM-5 & 20 & 5 & 12 & 5 & 5 & 0.4 & 9 & 2 & 41.6 \\
YWM-10 & 15 & 10 & 12 & 5 & 5 & 0.4 & 9 & 2 & 41.6 \\
YWM-15 & 10 & 15 & 12 & 5 & 5 & 0.4 & 9 & 2 & 41.6 \\
\hline
\end{tabular}

${ }^{1)}$ SJM, Shinjami sweet potato added Kochujang, YWM, Yeonwhangmi sweet potato added Kochujang. 


\section{결과 및 고찰}

\section{미생물상}

고구마를 이용한 고추장의 발효 중 미생물상 변화는 Table 2 와 같이 효모수는 대조구를 제외하고는 숙성 8 주까 지 증가하였고 그 이후에는 감소하였다. 시험구간에는 발 효 초기에 고구마를 혼합한 구에서 효모의 증식이 빨랐으나 발효 후기에는 오히려 감소하는 경향이었다. 이러한 경향 은 감귤 농축액(12)과 다시마와 키토산(16)을 첨가한 고추 장에서 숙성 4 8주까지 효모수가 증가되었던 보고(11)와
유사하였으며, 전통식 고추장에서도 발효 60 일까지 효모수 는 증가하여 3.86 5.15 $\log \mathrm{CFU} / \mathrm{g}$ 수준이었다(3).

세균수는 호기성 세균이 혐기성 세균에 비하여 발효중에 $1 \sim 2 \log$ CFU 정도 많았으나 시험구간의 차이는 없었다. 호기성 세균수는 발효 4주경에 $1 \log \mathrm{CFU}$ 정도 증가하였고 그 이후에는 감소하였으며, 혐기성 세균수는 발효 4 주 이후 에 감소하는 경향이었다. 이러한 경향은 호박 첨가 고추장 (13)의 경우 세균수가 담금 직후 $10^{8} \mathrm{CFU} / \mathrm{g}$ 에서 30 일 이후 에는 $10^{7} \mathrm{CFU} / \mathrm{g}$ 수준으로 감소하였고, 마늘과 양파(4)를 첨 가한 전통고추장은 각각 발효 6 10주와 12 주 까지 호기성

Table 2. Changes in viable cell counts of microorganism of Kochujang during fermentation

(unit: $\log \mathrm{CFU} / \mathrm{g}$ )

\begin{tabular}{|c|c|c|c|c|c|c|c|c|}
\hline \multirow{2}{*}{ Component } & \multirow{2}{*}{$\begin{array}{l}\text { Fermentation time } \\
\text { (weeks) }\end{array}$} & \multicolumn{7}{|c|}{ Kochujang ${ }^{1)}$} \\
\hline & & Control & SJM-5 & SJM-10 & SJM-15 & YWM-5 & YWM-10 & YWM-15 \\
\hline \multirow{4}{*}{ Yeast } & 0 & $3.08 \pm 0.54^{2)(3)}$ & $3.30 \pm 0.54^{\mathrm{bc}}$ & $4.52 \pm 0.39^{\mathrm{a}}$ & $4.63 \pm 0.34^{\mathrm{a}}$ & $3.96 \pm 0.55^{\mathrm{ab}}$ & $4.11 \pm 0.56^{\mathrm{ab}}$ & $4.54 \pm 0.24^{\mathrm{a}}$ \\
\hline & 4 & $4.58 \pm 0.58^{\mathrm{c}}$ & $5.85 \pm 0.28^{\mathrm{a}}$ & $5.84 \pm 0.47^{\mathrm{ab}}$ & $5.93 \pm 0.31^{\mathrm{a}}$ & $5.17 \pm 0.71^{\mathrm{a}}$ & $5.56 \pm 0.42^{\mathrm{ab}}$ & $4.95 \pm 0.46^{\mathrm{bc}}$ \\
\hline & 8 & $5.38 \pm 0.54$ & $5.96 \pm 0.42$ & $6.14 \pm 0.23$ & $5.72 \pm 0.43$ & $5.95 \pm 0.60$ & $5.84 \pm 0.59$ & $5.51 \pm 0.45$ \\
\hline & 12 & $6.05 \pm 0.59^{\mathrm{a}}$ & $5.05 \pm 0.39^{\mathrm{b}}$ & $4.91 \pm 0.47^{b}$ & $4.51 \pm 0.51^{\mathrm{b}}$ & $4.90 \pm 0.41^{\mathrm{b}}$ & $4.97 \pm 0.53^{b}$ & $4.86 \pm 0.52^{b}$ \\
\hline \multirow{4}{*}{ Aerobic bacteria } & 0 & $8.17 \pm 0.39$ & $8.20 \pm 0.41$ & $8.17 \pm 0.46$ & $8.17 \pm 0.68$ & $8.16 \pm 0.34$ & $8.21 \pm 0.13$ & $8.22 \pm 0.45$ \\
\hline & 4 & $9.66 \pm 0.23$ & $9.75 \pm 0.33$ & $9.69 \pm 0.50$ & $9.70 \pm 0.19$ & $9.78 \pm 0.39$ & $9.87 \pm 0.41$ & $9.82 \pm 0.51$ \\
\hline & 8 & $8.77 \pm 0.24$ & $8.61 \pm 0.50$ & $9.09 \pm 0.41$ & $9.21 \pm 0.47$ & $9.02 \pm 0.30$ & $9.27 \pm 0.48$ & $9.60 \pm 0.31$ \\
\hline & 12 & $8.84 \pm 0.29$ & $8.55 \pm 0.52$ & $8.91 \pm 0.49$ & $8.26 \pm 0.56$ & $9.19 \pm 0.47$ & $9.20 \pm 0.29$ & $8.96 \pm 0.61$ \\
\hline \multirow{4}{*}{ Anaerobic bacteria } & 0 & $7.18 \pm 0.44$ & $7.32 \pm 0.43$ & $7.17 \pm 0.46$ & $7.19 \pm 0.52$ & $7.65 \pm 0.49$ & $7.50 \pm 0.39$ & $7.72 \pm 0.41$ \\
\hline & 4 & $7.30 \pm 0.10$ & $7.58 \pm 0.37$ & $7.96 \pm 0.41$ & $7.25 \pm 0.53$ & $8.08 \pm 0.58$ & $7.21 \pm 0.66$ & $7.03 \pm 0.32$ \\
\hline & 8 & $6.65 \pm 0.32$ & $6.81 \pm 0.58$ & $6.89 \pm 0.55$ & $6.71 \pm 0.23$ & $6.85 \pm 0.68$ & $6.85 \pm 0.30$ & $6.71 \pm 0.51$ \\
\hline & 12 & $6.58 \pm 0.42$ & $6.71 \pm 0.60$ & $6.98 \pm 0.52$ & $6.95 \pm 0.63$ & $7.06 \pm 0.58$ & $7.03 \pm 0.46$ & $7.00 \pm 0.35$ \\
\hline
\end{tabular}

${ }^{1)}$ SJM, Shinjami sweet potato added Kochujang, YWM, Yeonwhangmi sweet potato added Kochujang.

${ }^{2)}$ Values are mean $\pm \mathrm{SD}(\mathrm{n}=3)$.

${ }^{3)}$ Means with same letter in raw are not significantly different by Duncan's multiple range test $(\mathrm{p}<0.05)$.

Table 3. Changes in amylase activity of Kochujang during fermentation

(unit: unit/g)

\begin{tabular}{|c|c|c|c|c|c|c|c|c|}
\hline \multirow{2}{*}{ Component } & \multirow{2}{*}{$\begin{array}{l}\text { Fermentation } \\
\text { time (weeks) }\end{array}$} & \multicolumn{7}{|c|}{ Kochujang ${ }^{1)}$} \\
\hline & & Control & SJM-5 & SJM-10 & SJM-15 & YWM-5 & YWM-10 & YWM-15 \\
\hline \multirow{4}{*}{ a-Amylase } & 0 & $4.18 \pm 0.07^{2 / b 3)}$ & $4.34 \pm 0.11^{b}$ & $4.84 \pm 0.32^{\mathrm{a}}$ & $4.96 \pm 0.34^{\mathrm{a}}$ & $4.47 \pm 0.19^{\mathrm{ab}}$ & $4.60 \pm 0.08^{\mathrm{ab}}$ & $4.75 \pm 0.36^{\mathrm{ab}}$ \\
\hline & 4 & $4.27 \pm 0.08^{\mathrm{ab}}$ & $4.14 \pm 0.15^{\mathrm{abc}}$ & $4.32 \pm 0.02^{\mathrm{a}}$ & $3.93 \pm 0.23^{\mathrm{abc}}$ & $3.96 \pm 0.40^{\mathrm{bc}}$ & $3.88 \pm 0.14^{c}$ & $4.24 \pm 0.13^{\mathrm{abc}}$ \\
\hline & 8 & $2.52 \pm 0.37$ & $2.52 \pm 0.22$ & $2.77 \pm 0.25$ & $2.38 \pm 0.31$ & $2.63 \pm 0.35$ & $2.69 \pm 0.11$ & $2.84 \pm 0.32$ \\
\hline & 12 & $1.40 \pm 0.18^{\mathrm{b}}$ & $1.39 \pm 0.40^{b}$ & $1.96 \pm 0.15^{\mathrm{a}}$ & $2.23 \pm 0.19^{\mathrm{a}}$ & $1.37 \pm 0.41^{b}$ & $2.04 \pm 0.05^{\mathrm{a}}$ & $1.88 \pm 0.26^{\mathrm{ab}}$ \\
\hline \multirow{4}{*}{$\begin{array}{c}\beta \text {-Amylase } \\
(\times 100)\end{array}$} & 0 & $1.94 \pm 0.10$ & $1.89 \pm 0.05$ & $1.73 \pm 0.21$ & $1.71 \pm 0.09$ & $1.85 \pm 0.27$ & $1.74 \pm 0.15$ & $1.76 \pm 0.22$ \\
\hline & 4 & $4.83 \pm 0.31^{\mathrm{d}}$ & $5.75 \pm 0.41^{\mathrm{c}}$ & $5.68 \pm 0.50^{c}$ & $5.58 \pm 0.15^{\complement}$ & $7.47 \pm 0.44^{\mathrm{cd}}$ & $8.01 \pm 0.16^{\mathrm{a}}$ & $7.31 \pm 0.58^{b}$ \\
\hline & 8 & $10.65 \pm 0.36^{\mathrm{a}}$ & $10.26 \pm 0.48^{\mathrm{ab}}$ & $9.94 \pm 0.53^{\mathrm{ab}}$ & $10.58 \pm 0.45^{\mathrm{a}}$ & $8.89 \pm 0.52^{\mathrm{c}}$ & $9.04 \pm 0.39^{c}$ & $9.65 \pm 0.32^{\mathrm{bc}}$ \\
\hline & 12 & $9.06 \pm 0.47^{\mathrm{bc}}$ & $8.45 \pm 0.23^{\mathrm{dc}}$ & $9.49 \pm 0.11^{\mathrm{ab}}$ & $9.22 \pm 0.32^{\mathrm{b}}$ & $7.96 \pm 0.15^{\mathrm{c}}$ & $9.05 \pm 0.50^{\mathrm{a}}$ & $8.37 \pm 0.18^{\text {cd }}$ \\
\hline
\end{tabular}

${ }^{1)}$ SJM, Shinjami sweet potato added Kochujang, YWM, Yeonwhangmi sweet potato added Kochujang.

${ }^{2)}$ Values are mean \pm SD $(n=3)$.

${ }^{3)}$ Means with same letter in raw are not significantly different by Duncan's multiple range test $(p<0.05)$. 
세균이 증가되었던 보고와는 차이가 있었다. 이는 본 고추 장이 국균 koji에 호기성 세균인 청국장 koji를 혼합하였기 때문에 발효 초기에 고추장중의 호기성 세균이 일반 고추장 에 비하여 상대적으로 많아 숙성중 증가가 적었기 때문이며 홍감자를 이용한 고추장(11)에서도 유사한 경향이었다.

\section{효소활성도}

고추장 발효중 효소활성도의 변화는 Table 3,4 와 같다. a-amylase는 발효중 서서히 감소하였으나, 고구마의 혼합 비율이 높은 구에서 a-amylase 활성은 조금 높았으며 연황 미 품종보다는 신자미를 혼합한 고추장에서 효소활성이 높았다. $\beta$-amylase는 이와는 달리 발효 8주까지 효소활성도 는 증가되었고 그 이후에 감소하는 경향이었다. 시험구간 에는 고구마를 5 10\% 혼합한 구에서 발효초기 효소활성이 높았으나 중기 이후에는 효소활성의 차이는 없었다. 이러 한 경향은 순창고추장의 a-amylase는 발효 90일경에 최대 활성을 보였으나 $\beta$-amylase는 120 일경 까지 활성이 증가하 였던 김(1)의 보고와 전분액화력과 당화력 모두 발효 20 일 경에 최대 활성을 보였던 조 등(2)의 보고와 차이가 있었는 데 이는 본 실험구들이 국균 koji에 청국장 koji를 혼합하였 기 때문에 국균 kojp만을 이용한 고추장과는 발효중 효소활 성도에서도 차이가 있었던 것으로 판단되었다.

단백질 분해효소의 활성은 담금 초기에는 산성 protease 활성이 중성 protease에 비하여 현저히 높았으며, 산성 protease의 활성은 발효 중에 서서히 감소하다가 8주 이후에 증가하였다. 중성 protease는 이와는 달리 발효 4주에 효소 활성이 증가되었고 그 이후에 감소하였으나 12 주에 다시 증가하여 효소활성의 변화가 심하였다. 시험구간에는 고구 마 혼합비율이 높은 구에서 발효 후기에 효소활성이 낮은 경향이었다. 이러한 경향은 전통식 고추장(3)에서 담금 직 후에는 산성 protease 활성이 높지만 발효 중기에는 중성
(A)

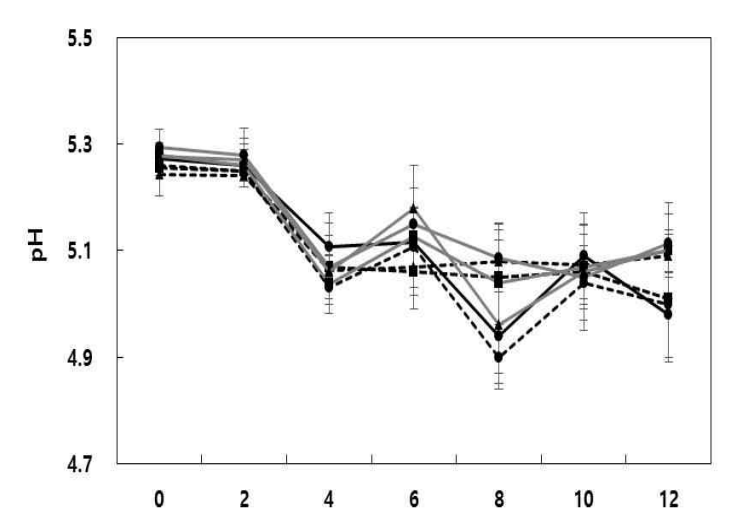

(B)

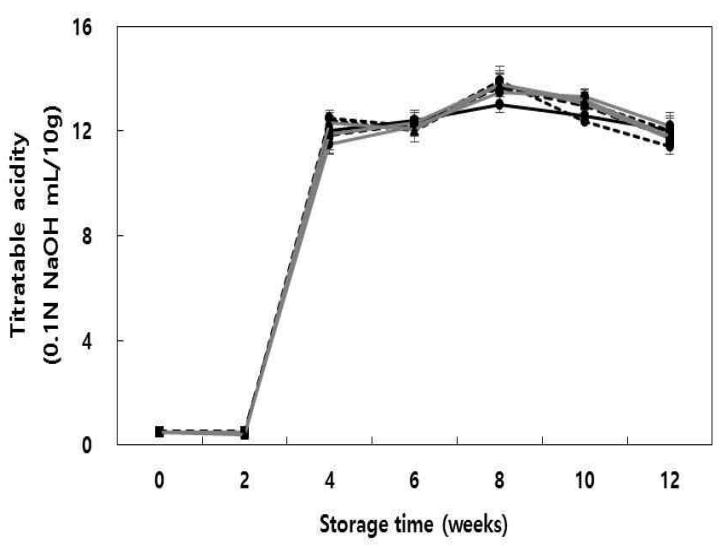

Fig. 1. Changes in pH (A) and titratable acidity (B) of Kochujang during fermentation.

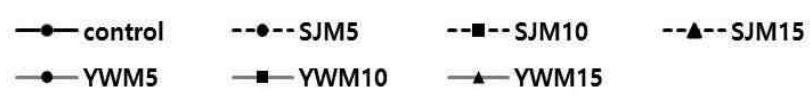

SIM, Shinjami sweet potato added Kochujang, YWM, Yeonwhangmi sweet potato added Kochujang.

protease 활성이 높았던 보고와 유사하였으나, 고추장의 단 백질 분해는 산성 protease가 주체가 되었던 보고(1)와는

Table 4. Changes in protease activity of Kochujang during fermentation

(unit: unit/g)

\begin{tabular}{|c|c|c|c|c|c|c|c|c|}
\hline \multirow{2}{*}{ Component } & \multirow{2}{*}{$\begin{array}{l}\text { Fermentation } \\
\text { time (weeks) }\end{array}$} & \multicolumn{7}{|c|}{ Kochujang } \\
\hline & & Control & SJM-5 & SJM-10 & SJM-15 & YWM-5 & YWM-10 & YWM-15 \\
\hline \multirow{4}{*}{ Acidic protease } & 0 & $5.57 \pm 0.25^{2) a b 3)}$ & $6.01 \pm 0.39^{\mathrm{a}}$ & $6.16 \pm 0.31^{a}$ & $5.51 \pm 0.27^{\mathrm{ab}}$ & $5.03 \pm 0.35^{b}$ & $5.05 \pm 0.10^{b}$ & $4.59 \pm 0.77^{b}$ \\
\hline & 4 & $3.13 \pm 0.17^{b c}$ & $3.66 \pm 0.27^{\mathrm{ab}}$ & $3.28 \pm 0.41^{\mathrm{abc}}$ & $3.62 \pm 0.32^{\mathrm{ab}}$ & $2.48 \pm 0.52^{d}$ & $3.73 \pm 0.24^{\mathrm{a}}$ & $2.92 \pm 0.19^{\mathrm{cd}}$ \\
\hline & 8 & $5.01 \pm 0.19^{\mathrm{a}}$ & $3.29 \pm 0.32^{b}$ & $4.89 \pm 0.45^{\mathrm{a}}$ & $3.31 \pm 0.03^{b}$ & $5.49 \pm 0.16^{\mathrm{a}}$ & $5.05 \pm 0.33^{\mathrm{a}}$ & $3.15 \pm 0.29^{c}$ \\
\hline & 12 & $9.39 \pm 0.40^{\mathrm{a}}$ & $8.36 \pm 0.35^{b}$ & $7.71 \pm 0.18^{c}$ & $5.97 \pm 0.40^{\mathrm{e}}$ & $7.04 \pm 0.45^{\mathrm{d}}$ & $7.27 \pm 0.29^{\mathrm{cd}}$ & $5.59 \pm 0.27^{e}$ \\
\hline \multirow{4}{*}{ Neutral protease } & 0 & $1.91 \pm 0.37$ & $2.24 \pm 0.20$ & $2.38 \pm 0.32$ & $2.07 \pm 0.21$ & $1.84 \pm 0.23$ & $1.97 \pm 0.40$ & $1.74 \pm 0.06$ \\
\hline & 4 & $4.32 \pm 0.27^{e}$ & $4.81 \pm 0.22^{\mathrm{d}}$ & $4.91 \pm 0.09^{\mathrm{e}}$ & $7.33 \pm 0.24^{\mathrm{a}}$ & $4.25 \pm 0.28^{\mathrm{e}}$ & $6,31 \pm 0.14^{b}$ & $5.66 \pm 0.09^{c}$ \\
\hline & 8 & $3.09 \pm 0.26$ & $2.91 \pm 0.29$ & $2.90 \pm 0.09$ & $2.84 \pm 0.27$ & $2.98 \pm 0.22$ & $3.00 \pm 0.12$ & $3.09 \pm 0.31$ \\
\hline & 12 & $10.30 \pm 0.15^{\mathrm{a}}$ & $6.75 \pm 0.12^{\mathrm{e}}$ & $7.69 \pm 0.45^{\mathrm{d}}$ & $5.94 \pm 0.32^{\mathrm{f}}$ & $6.58 \pm 0.11^{\mathrm{e}}$ & $8.55 \pm 0.30^{b}$ & $8.13 \pm 0.16^{c}$ \\
\hline
\end{tabular}

\footnotetext{
${ }^{1)}$ SJM, Shinjami sweet potato added Kochujang, YWM, Yeonwhangmi sweet potato added Kochujang.

${ }^{2)}$ Values are mean $\pm \mathrm{SD}(\mathrm{n}=3)$.

${ }^{3)}$ Means with same letter in raw are not significantly different by Duncan's multiple range test $(p<0.05)$.
} 
차이가 있었다. 따라서 본 실험 고추장에서 단백질의 분해 는 담금 직후에 산성 protease활성이 높았지만 고추장 $\mathrm{pH}$ 가 발효 중에 pH 5.0 이상(Fig. 1A)이기 때문에 고추장의 숙성 은 중성 protease에 의해 진행되며, 고구마 혼합에 의한 숙성 중 효소활성은 영향은 적은 것으로 판단되었다.

\section{색 도}

고추장의 색을 Hunter 색차계로 측정한 결과는 Table 5 와 같다. 담금 직후에는 $\mathrm{L}, \mathrm{a}, \mathrm{b}$ 값 모두 신자미보다 호박고구마 인 연황미 고추장에서 높아 밝은 색을 띄었다. 발효 중의 변화는 밝기인 L값은 신자미보다 연황미 고추장에서 숙성 중에 저하가 심하였으나 12 주 후에는 큰 차이가 없었다. 적색도인 $\mathrm{a}$ 값과 황색도인 $\mathrm{b}$ 값은 발효 2 주경에 급격히 저하 되었고 그 이후에는 근소하게 저하되었다. 시험구간에는 연황미 고추장이 자색고구마인 신자미 고추장에 비하여 $a$ 와 $b$ 값이 높이 진한 색을 띠었다. 이러한 경향은 강황(7)과
감귤농축액(12), 사과과즙(14)을 첨가한 고추장에서 $\mathrm{L}, \mathrm{a}$, $\mathrm{b}$ 값이 숙성이 진행되면서 점진적으로 저하되었던 보고들 과 유사하였으나, 양파와 마늘(5)을 첨가한 경우 $\mathrm{a}$ 값이 발효 후기에 조금 증가되었던 보고와는 다소 차이가 있었다. 고 추장의 색에 대한 기호도와 색 지표 간에는 $\mathrm{L}, \mathrm{a}, \mathrm{b}$ 값이 0.9224 0.9535로 높은 상관관계가 있는 것으로 보고되었다 (15). 또한 고추장의 색은 orange pink로 주파장이 594 597 $\mathrm{nm}$ 이나 발효가 진행됨에 따라 길어지며, $\mathrm{L}$ 과 $\mathrm{a}, \mathrm{b}$ 값 모두 점진적으로 감소되었다고 보고(9)된 바 있다. 고추장의 변 색도인 total color difference $(\Delta \mathrm{E})$ 값은 Table 6 과 같이 연황 미 고추장은 고구마 첨가비율이 증가할수록 발효 중에 변색 정도가 심하였으나 신자미의 경우 변색도가 적어 자색고구 마가 호박고구마에 비하여 색상이 안정한 편이었다. 고추 장의 변색 요인은 Maillard 반응에 의한 $\mathrm{HMF}$ 생성 이외에도 고추장 원료의 산화와 효소반응이 함께 작용하는 것으로 추정된 바 있다 $(9,12)$.

Table 5. Changes in color values of Kochujang during fermentation

\begin{tabular}{|c|c|c|c|c|c|c|c|c|}
\hline \multirow{2}{*}{ Component } & \multirow{2}{*}{$\begin{array}{l}\text { Fermentation time } \\
\text { (weeks) }\end{array}$} & \multicolumn{7}{|c|}{ Kochujang } \\
\hline & & Control & SJM-5 & SJM-10 & SJM-15 & YWM-5 & YWM-10 & YWM-15 \\
\hline \multirow{4}{*}{$\mathrm{L}$} & 0 & $36.16 \pm 0.44^{22) a 3)}$ & $33.80 \pm 0.24^{\mathrm{c}}$ & $32.66 \pm 0.31^{\mathrm{d}}$ & $29.68 \pm 0.23^{\mathrm{e}}$ & $35.67 \pm 0.25^{b}$ & $36.18 \pm 0.14^{\mathrm{a}}$ & $36.51 \pm 0.25^{\mathrm{a}}$ \\
\hline & 4 & $32.82 \pm 0.39^{b c}$ & $32.74 \pm 0.33^{\mathrm{bc}}$ & $32.49 \pm 0.08^{\mathrm{c}}$ & $31.58 \pm 0.33^{\mathrm{d}}$ & $33.56 \pm 0.22^{a}$ & $33.23 \pm 0.26^{\mathrm{ab}}$ & $32.81 \pm 0.34^{\mathrm{bc}}$ \\
\hline & 8 & $32.75 \pm 0.14^{\mathrm{a}}$ & $33.17 \pm 0.38^{a}$ & $32.38 \pm 0.59^{\mathrm{b}}$ & $30.72 \pm 0.24^{\mathrm{c}}$ & $32.63 \pm 0.53^{\mathrm{b}}$ & $32.37 \pm 0.34^{b}$ & $33.55 \pm 0.33^{\mathrm{a}}$ \\
\hline & 12 & $32.60 \pm 0.39^{\mathrm{ab}}$ & $31.93 \pm 0.15^{\mathrm{c}}$ & $32.07 \pm 0.28^{\mathrm{bc}}$ & $31.02 \pm 0.44^{\mathrm{d}}$ & $32.73 \pm 0.20^{\mathrm{a}}$ & $32.70 \pm 0.35^{\mathrm{a}}$ & $32.38 \pm 0.25^{\mathrm{ab}}$ \\
\hline \multirow{4}{*}{$\mathrm{a}$} & 0 & $25.35 \pm 0.34^{b}$ & $25.39 \pm 0.28^{b}$ & $24.99 \pm 0.42^{\mathrm{bc}}$ & $24.77 \pm 0.23^{c}$ & $26.07 \pm 0.29^{\mathrm{a}}$ & $26.22 \pm 0.27^{a}$ & $26.27 \pm 0.28^{a}$ \\
\hline & 4 & $21.43 \pm 0.27^{\mathrm{a}}$ & $20.18 \pm 0.21^{\mathrm{c}}$ & $20.19 \pm 0.07^{c}$ & $19.27 \pm 0.16^{d}$ & $20.56 \pm 0.27^{\mathrm{bc}}$ & $20.72 \pm 0.28^{b}$ & $20.29 \pm 0.32^{b c}$ \\
\hline & 8 & $20.70 \pm 0.29^{\mathrm{a}}$ & $20.00 \pm 0.29^{a}$ & $18.92 \pm 0.26^{b}$ & $18.78 \pm 0.28^{b}$ & $20.27 \pm 0.30^{\mathrm{a}}$ & $20.31 \pm 0.32^{\mathrm{a}}$ & $20.07 \pm 0.25^{a}$ \\
\hline & 12 & $19.71 \pm 0.18^{\mathrm{bc}}$ & $19.96 \pm 0.19^{\mathrm{ab}}$ & $19.21 \pm 0.27^{\mathrm{cd}}$ & $18.88 \pm 0.34^{\mathrm{d}}$ & $20.19 \pm 0.40^{\mathrm{a}}$ & $19.94 \pm 0.09^{\mathrm{ab}}$ & $19.88 \pm 0.32^{\mathrm{ab}}$ \\
\hline \multirow{4}{*}{ b } & 0 & $28.44 \pm 0.24^{\mathrm{c}}$ & $26.16 \pm 0.14^{d}$ & $23.83 \pm 0.29^{\mathrm{e}}$ & $20.54 \pm 0.14^{f}$ & $30.40 \pm 0.23^{b}$ & $31.52 \pm 0.22^{\mathrm{a}}$ & $31.69 \pm 0.41^{\mathrm{a}}$ \\
\hline & 4 & $23.85 \pm 0.26^{\mathrm{a}}$ & $22.99 \pm 0.22^{b}$ & $22.16 \pm 0.39^{c}$ & $19.95 \pm 0.19^{d}$ & $23.24 \pm 0.54^{\mathrm{ab}}$ & $23.68 \pm 0.43^{\mathrm{ab}}$ & $23.87 \pm 0.73^{\mathrm{a}}$ \\
\hline & 8 & $23.36 \pm 0.22^{\mathrm{ab}}$ & $22.17 \pm 0.12^{\mathrm{b}}$ & $22.85 \pm 0.17^{b}$ & $20.04 \pm 0.19^{d}$ & $23.70 \pm 0.31^{\mathrm{a}}$ & $23.32 \pm 0.33^{\mathrm{ab}}$ & $20.89 \pm 0.67^{c}$ \\
\hline & 12 & $22.89 \pm 0.53^{\mathrm{a}}$ & $22.01 \pm 0.41^{b}$ & $21.81 \pm 0.69^{c}$ & $20.12 \pm 0.11^{\mathrm{c}}$ & $23.12 \pm 0.35^{\mathrm{a}}$ & $23.34 \pm 0.27^{\mathrm{a}}$ & $22.75 \pm 0.38^{\mathrm{ab}}$ \\
\hline
\end{tabular}

${ }^{1)}$ SJM, Shinjami sweet potato added Kochujang, YWM, Yeonwhangmi sweet potato added Kochujang.

${ }^{2)}$ Values are mean \pm SD $(n=3)$.

${ }^{3)}$ Means with same letter in raw are not significantly different by Duncan's multiple range test $(\mathrm{p}<0.05)$.

Table 6. Changes in total color difference of Kochujang during fermentation

\begin{tabular}{ccccccrrr}
\hline \multirow{2}{*}{$\begin{array}{c}\text { Fermentation } \\
\text { time (weeks) }\end{array}$} & \multicolumn{9}{c}{ Kochujang $^{\mathrm{l}}$} \\
\cline { 2 - 8 } & Control & SJM-5 & SJM-10 & SJM-15 & YWM-5 & YWM-10 & YWM-15 \\
\hline 2 & 6.19 & 5.96 & 5.35 & 5.67 & 7.01 & 7.98 & 8.53 \\
4 & 6.89 & 6.19 & 5.09 & 5.43 & 9.28 & 10.02 & 10.52 \\
6 & 7.45 & 5.94 & 5.36 & 5.83 & 9.03 & 9.95 & 10.90 & 12.80 \\
8 & 7.68 & 6.72 & 6.15 & 6.10 & 9.37 & 9.80 & 11.67 & 11.32 \\
10 & 9.43 & 7.31 & 6.19 & 5.25 & 9.45 & 9.67 & 10.88 & 11.74 \\
12 & 8.68 & 7.61 & 6.15 & 6.06 & & &
\end{tabular}

${ }^{1)}$ SJM, Shinjami sweet potato added Kochujang, YWM, Yeonwhangmi sweet potato added Kochujang. 


\section{$\mathrm{pH}$ 와 적정산도}

고추장 발효중 $\mathrm{pH}$ 의 변화는 Fig. 1 과 같이 담금시 $\mathrm{pH}$ 5.25 5.29에서 발효가 진행되면서 저하되어 12 주 후에는 $\mathrm{pH}$ 4.98 5.11이었다. 시험구간에는 고구마의 혼합비율이 높은 구에서 $\mathrm{pH}$ 는 높은 경향이었다. 본 실험 고구마 첨가 고추장의 $\mathrm{pH}$ 는 전라북도 지역 전통고추장이 평균 $\mathrm{pH}$ 4.62(8), 잡곡류를 혼합한 고추장은 120 일 발효 후 $\mathrm{pH}$ 가 4.3 4.7이었던 보고(10)에 비하여 알코올을 첨가한 관계로 유기산 생성이 적어 $\mathrm{pH}$ 가 높은 편이었다.

적정산도는 발효 중에 $\mathrm{pH}$ 가 저하됨에 따라 발효 4주에 급격히 증가되었으나 8 주 이후에는 감소하는 경향을 보였 다. 시험구간에는 고구마의 혼합비율이 높은 구에서 적정 산도도 높았는데 이는 이들 고추장이 발효 중기에 효모수와 호기성 세균수(Table 2)가 많았던 결과로 미루어보아 발효 중 미생물의 증식에 의한 유기산 생성에 기인하는 것으로 판단되었다. 한편 고추장은 내염성 유산균이나 산생성균이 발효 초기에 생육하여 $\mathrm{pH}$ 를 저하시키고 산도를 증가시키 나(2), 발효 후기에는 생성된 알코올과 유기산이 ester화되

(A)

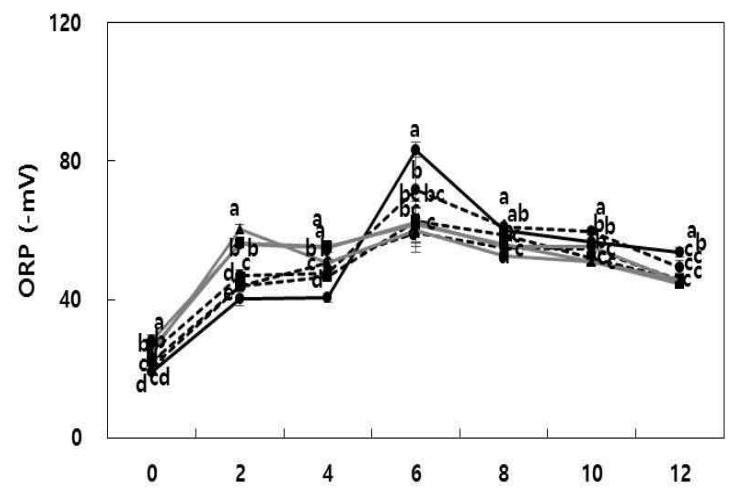

(B)

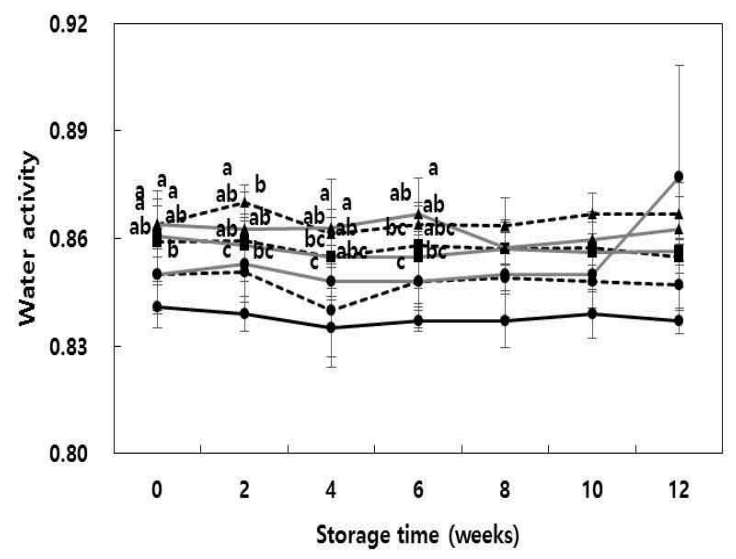

Fig. 2. Changes in oxidation-reduction potential (A) and water activity (B) of Kochujang during fermentation.

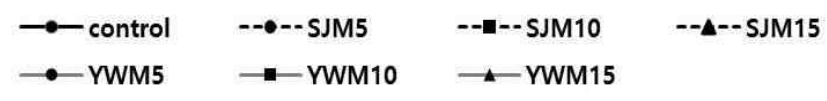

SJM, Shinjami sweet potato added Kochujang, YWM, Yeonwhangmi sweet potato added Kochujang.
고(5), Bacillus subtilis가 분비하는 deaminase에 의해 아미노 산이 감소되어 산도는 감소한다고 보고 된 바 있다(12). 본 실험의 경우에는 고추장 발효 중 $\mathrm{pH}$ 와 적정산도의 변화 는 상대적으로 적었는데, 이는 고추장 담금시 알코올을 $2 \%$ 첨가하여 발효 중에 유기산 생성균의 증식이 억제되었기 때문이다.

\section{산화환원전위와 수분활성도}

고추장의 산화환원전위(ORP, oxidation-reduction potential) 는 Fig. 2 와 같이 발효 6 주까지 저하되었으나 그 이후에는 서서히 증가되었다. 시험구간에는 고구마의 혼합 비율이 높은 고추장에서 발효후기에 산화환원전위가 높았다. 산화 환원전위가 $-200 \mathrm{mV}$ 이하로 낮아지면 혐기성세균의 증식 이 유리한 환경이 되어 호기성균의 증식은 불리하여 진다고 보고(23) 되었으나, 본 실험 고추장의 산화환원전위는 발효 중에 호기성 세균의 증식에 영향을 주는 수준은 아니었다.

고추장의 수분활성도 변화는 발효 4주까지 점진적으로 감소되었고 그 이후에는 불규칙한 증감을 보였다. 시험구 별로는 고구마의 혼합비율이 높은 구에서 수분활성도가 높았는데 이는 멥쌀에 비하여 고구마의 수분함량이 많았기 때문이며, 고추장의 수분활성도 저하는 발효가 진행되면서 원료성분이 분해되어 저분자화 됨에 따라 용질의 몰분율이 증가하기 때문이다(5). 그러나 전통고추장의 수분활성도가 0.816 0.818(16)이었던 보고에 비하여 본 실험 고추장의 수분활성도는 높았는데, 이는 항아리에서 자연 숙성시키면 수분의 증발로 수분활성도가 감소하기 때문이다(10).

\section{환원당과 알코올}

고추장의 단맛 성분으로 중요한 환원당은 Fig. 3과 같이 발효 2주에 급격히 증가된 후 4 8주까지 근소하게 증가되 었으나 그 이후에는 미생물과 유기산의 발효기질로 이용되 어 감소하였다(14). 시험구간에는 고구마의 혼합비율이 높 은 고추장에서 환원당 함량이 적었다. 환원당 함량은 전북 지방 전통고추장이 평균 $19.46 \%$ 이었던 보고(8)에 비하여 낮은 수준이었는데 이는 본 실험 고추장이 담금시 물엿이나 조청을 첨가하지 않았기 때문이다.

고추장의 풍미에 영향을 주는 알코올 함량은 고추장 담 금시 $2.0 \%$ 를 첨가하였지만, 배합과정에서 휘발되어 담금 직후에 1.36 1.43\%로 낮아졌으나 발효 2주 이후부터 서서 히 증가되어 8주에 1.76 2.12\%에 달하였고 그 이후에는 감소하였다. 알코올의 증가 경향은 Table 2 의 효모수 증가 와 유사하였고, 고구마를 혼합한 구가 멥쌀만 혼합한 대조 구에 비하여 알코올의 생성이 높아 고추장 숙성중 품질유지 에 유리한 것으로 판단되었다. 또한 알코올의 변화는 환원 당의 감소 경향과 유사하였고, $\mathrm{Kim}$ 등(11)은 고추장 담금시 알코올을 첨가하면 발효중 알코올의 변화는 미약하였다고 보고한 바 있다. 


\section{질소성분}

고추장의 아미노산성 질소와 암모니아성 질소 함량의 변화는 Fig. 4와 같다. 구수한 맛 성분으로 중요한 아미노산 성 질소는 멥쌀만으로 담근 대조구를 제외하고는 발효 중에 서서히 증가하여 12 주 발효 후에는 $0.33 \sim 0.35 \%$ 까지 증가되 었고, 발효 초기에는 고구마의 혼합비율이 높은 구가 대조 구에 비하여 단백질 함량이 적기 때문에 아미노산성 질소의 생성이 적었으나 12 주 발효 후에는 큰 차이가 없었다. 이러 한 경향은 잡곡류 첨가한 고추장(10)과 감귤농축액을 첨가 한 고추장(12)에서도 발효 중에 아미노산성 질소가 증가되 었던 보고와 유사하였다.

고추장 발효중 지나치면 불쾌한 맛의 원인이 될 수 있는 암모니아성 질소는 발효 10 주까지 증가한 후에 감소하여 대체적으로 아미노산성 질소의 변화와는 차이가 있었으며 증감의 정도는 아미노산성 질소에 비하여 심한 편이었다. 이러한 경향은 전통 고추장이 발효 150 일 까지 암모니아성 질소가 점진적으로 증가되었던 보고(1)와는 차이가 있었 다. 따라서 고추장의 질소성분의 변화는 $k o j i$ 의 종류와 고추 장 원료의 배합비율에 따라 차이가 심한 것으로 판단되었 다. 또한 전통고추장의 아미노산성 질소와 암모니아성 질

(A)

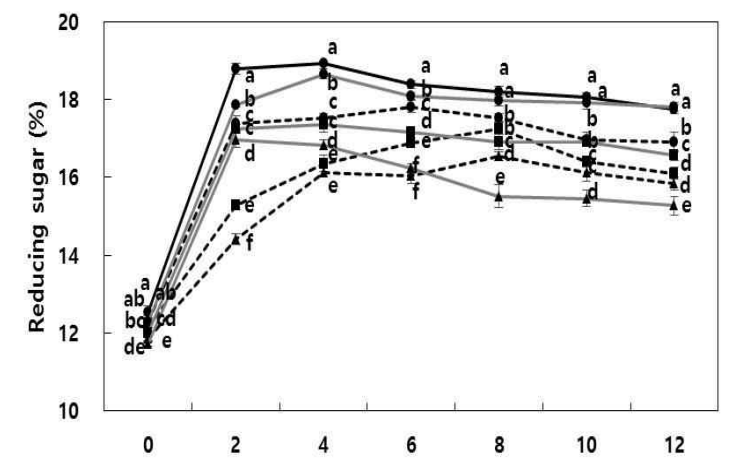

(B)

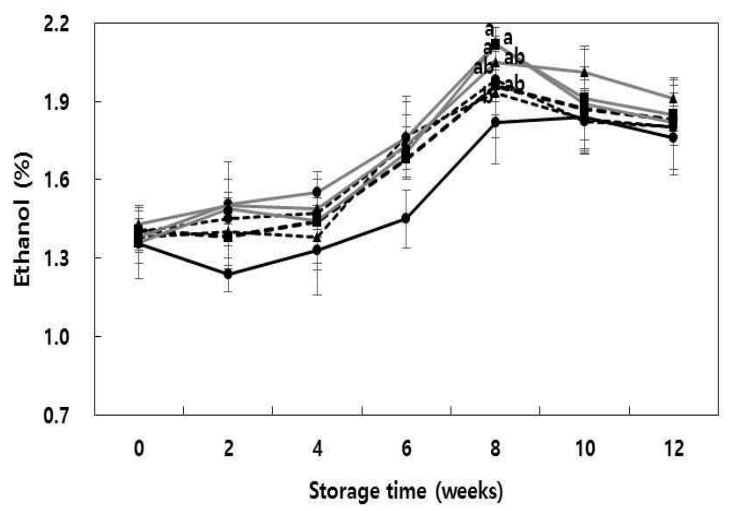

Fig. 3. Changes in reducing sugar (A) and ethanol contents (B) of Kochujang during fermentation.

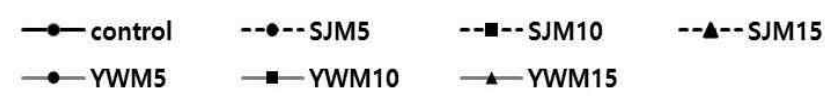

SJM, Shinjami sweet potato added Kochujang, YWM, Yeonwhangmi sweet potato added Kochujang.
소는 각각 평균 $0.123 \%$ 와 $32 \mathrm{mg} \%$ 이었던 보고(8)에 비하여 아미노산성 질소 함량은 높고 암모니아성 질소 함량은 낮았 는데 이는 고추장 담금시 알코올을 첨가하여 숙성중 이상발 효가 억제되었기 때문이다.

(A)

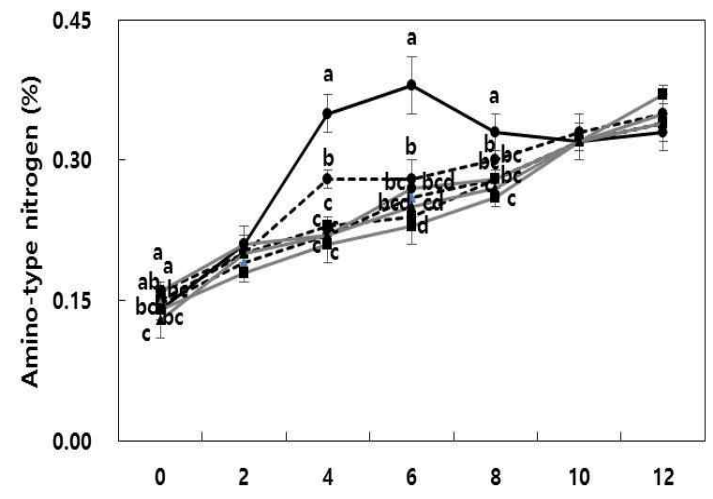

(B)

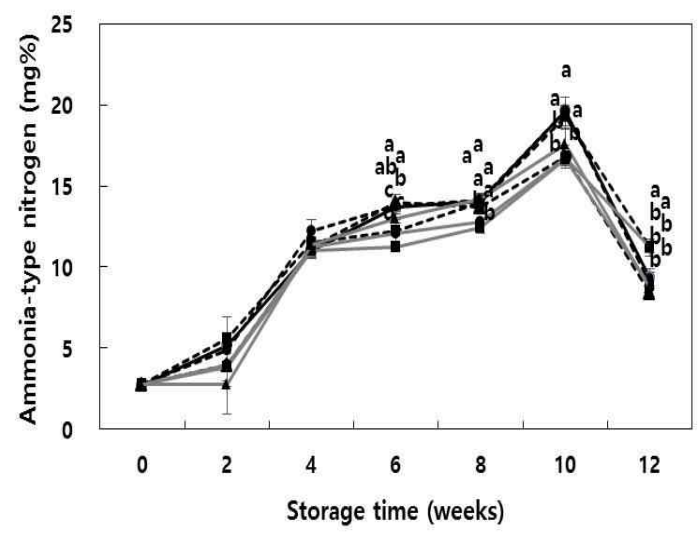

Fig. 4. Changes in amino nitrogen (A) and ammonia nitrogen contents (B) of Kochujang during fermentation.

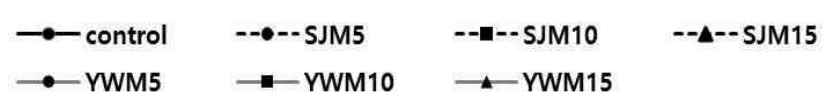

SJM, Shinjami sweet potato added Kochujang, YWM, Yeonwhangmi sweet potato added Kochujang.

관능검사

12 주 발효시킨 고추장을 관능 평가한 결과는 Table 7과 같이 맛은 연황미 고구마를 $5 \%$ 혼합한 고추장이 제일 좋았 고, 다음으로 연황미 $10 \%$, 신자미 $10 \%$ 를 첨가한 고추장이 멥쌀을 이용한 대조구에 비하여 양호하였으나 고구마를 $15 \%$ 첨가한 고추장은 대조구보다 낮은 판정을 받았다. 색은 신자미 $10 \%$ 와 $5 \%$ 를 혼합한 고추장이 대조구나 연황미 혼 합 고추장에 비하여 좋았다. 향기는 신자미를 $5 \%$ 와 $10 \%$ 혼합한 고추장이 대조구에 비하여 양호하였으나 연황미 혼합 고추장은 대조구보다 낮은 판정을 받았다. 전체적인 기호도는 신자미 고구마를 $10 \%$ 혼합한 고추장이 연황미 $15 \%$ 혼합고추장에 비하여 유의적으로 $(\mathrm{p}<0.05)$ 양호하였 고, 다음으로 신자미 $15 \%$, 연황미 $5 \%$ 혼합 고추장 순이었 다. 따라서 고구마를 이용한 고추장의 제조는 호박고구마 
보다 자색고구마인 신자미 품종을 이용하는 것이 관능적으 로 우수하였으며 혼합비율은 $10 \%$ 정도가 양호하였다.

Table 7. Result of sensory evaluation of Kochujang prepared with sweet potato and aged for 12 weeks

\begin{tabular}{ccccc}
\hline Kochujang $^{1)}$ & Taste & Color & Flavor & $\begin{array}{c}\text { Overall } \\
\text { acceptability }\end{array}$ \\
\hline Control & $4.10 \pm 1.12^{2)}$ & $4.20 \pm 1.24$ & $4.30 \pm 0.92$ & $4.30 \pm 0.98^{\mathrm{ab} 3)}$ \\
SJM-5 & $4.10 \pm 1.17$ & $4.80 \pm 1.20$ & $4.55 \pm 0.94$ & $4.20 \pm 1.24^{\mathrm{ab}}$ \\
SJM-10 & $4.35 \pm 1.39$ & $4.95 \pm 1.10$ & $4.50 \pm 1.19$ & $4.95 \pm 1.40^{\mathrm{a}}$ \\
SJM-15 & $3.95 \pm 1.00$ & $4.70 \pm 1.26$ & $4.20 \pm 1.44$ & $4.75 \pm 1.21^{\mathrm{ab}}$ \\
YWM-5 & $4.70 \pm 1.53$ & $4.20 \pm 1.20$ & $4.00 \pm 1.38$ & $4.70 \pm 1.34^{\mathrm{ab}}$ \\
YWM-10 & $4.45 \pm 1.54$ & $4.60 \pm 1.43$ & $4.15 \pm 1.35$ & $4.30 \pm 1.34^{\mathrm{ab}}$ \\
YWM-15 & $3.90 \pm 1.31$ & $4.25 \pm 1.27$ & $4.20 \pm 1.36$ & $3.85 \pm 1.50^{\mathrm{b}}$ \\
\hline
\end{tabular}

${ }^{1)}$ SJM, Shinjami sweet potato added Kochujang, YWM, Yeonwhangmi sweet potato added Kochujang.

${ }^{2)}$ Values are mean $\pm \mathrm{SD}$.

${ }^{3)}$ Means with the same letter in column are not significantly different by Duncan's multiple range test $(\mathrm{p}<0.05)$.

\section{요 약}

고추장 제조시 멥쌀의 일부를 고구마로 대체하여 고추장 발효 중 이화학적 특성을 비교하였다. 고구마를 혼합한 고 추장이 발효 후기에 효모수 감소가 심하였으나 세균수는 차이가 없었다. 고구마의 혼합비율이 증가할수록 $a$ -amylase 활성은 높았으나 protease 활성은 낮았다. 자색고 구마 혼합 고추장이 Hunter L, a, b값이 낮았으며 발효 중 $\Delta \mathrm{E}$ 값의 변화는 호박고구마 혼합구에서 심하였다. 고추장 의 $\mathrm{pH}$ 는 발효 8 주까지 저하되었으며, 적정산도는 4 주경에 급격히 증가하였다. 고구마 혼합 비율이 증가할수록 고추 장의 $\mathrm{ORP}$ 와 $\mathrm{Aw}$ 는 증가하였다. 고추장의 환원당은 고구마 혼합구에서 낮았으며, 알코올의 생성은 호박고구마 혼합 고추장에서 높았다. 아미노산성 질소는 고구마 혼합 고추 장에서 적었으나 발효 후기에는 큰 차이가 없었다. 고추장 의 맛은 호박고구마 5 10\%, 색상과 향기는 자색고구마 5 10\% 혼합구가 양호하였으며, 고구마를 이용한 고추장의 제조는 호박고구마보다 자색고구마인 신자미 품종을 이용 하는 것이 관능적으로 우수하였으며 혼합비율은 $10 \%$ 정도 가 양호하였다.

\section{References}

1. Kim YS (1993) Studies on the changes in physicochemical characteristics and volatile flavor compounds of traditional Kochujang during fermentation. Ph D Thesis.
King Sejong University, Korea, p 1-116

2. Cho HO, Park SA, Kim JG (1981) Effect of traditional and improved Kochujang koji on the quality improvement of traditional Kochujang. Korean J Food Sci Technol, 13, 319-327

3. Shin DH, Kim DH, Choi U, Lim MS, An EY (1997) Changes in microflora and enzymes activities of traditional Kochujang prepared with various raw materials. Korean J Food Sci Technol, 29, 901-906

4. Kim DH (2001) Effect of condiments on the microflora, enzyme activities and taste components of traditional Kochujang during fermentation. Korean J Food Sci Technol, 33, 264-270

5. Kim DH, Lee JS (2001) Effect of condiments on the physicochemical characteristics of traditional Kochujang during fermentation. Korean J Food Sci Technol, 33, 353-360

6. Shin DH, Ahn EY, Kim YS, Oh JY (2000) Fermentation characteristics of Kochujang containing horseradish or mustard. Korean J Food Sci Technol, 32, 1350-1357

7. Kim DH (2013) Effects of turmeric (Curcuma longa L.) on the physicochemical characteristics of Kochujang during fermentation. J Appl Biol Chem, 56, 101-107

8. Cho HO, Kim JG, Lee HJ, Kang JH, Lee TS (1981) Brewing method and composition of traditional Kochuzang (red pepper paste) in Junrabookdo area. J Appl Biol Chem, 24, 21-28

9. Moon TW. Kim ZU (1988) Some chemical physical characteristics and acceptability of Kochujang from various starch sources. J Appl Biol Chem, 31, 387-393

10. Kim YS, Hwang SJ (2005) Quality characteristics of traditional Kochujang added with concentrations of Korean various grain. Korean J Food Cook Sci, 21, 677-684

11. Kim OR, Kim DH (2012) Effect of red-potato on the physicochemical properties of Kochujang. J Korean Soc Food Sci Nutr, 41, 1805-1812

12. Chae IS, Kim HS, Ko YS, Kang MH, Hong SP, Shin DB (2008) Effect of citrus concentrate on the physicochemical properties of Kochujang. Korean J Food Sci Technol, 40, 626-632

13. Choo JJ, Shin HJ (2000) Sensory evaluation and changes in physiochemical properties, and microflora and enzyme activities of pumpkin added Kochujang. Korean J Food Sci Technol, 32, 851-859

14. Lee EY, Park GS (2009) Quality characteristics of Kochujang with addition of apple juices. Korean J Food 
Cook Sci, 25, 747-757

15. Ahn MR, Jeong DY, Hong SP, Song KS, Kim YS (2003) Quality of traditional Kochujang supplemented with mushrooms (Pleurotus ostreatus and Lentinus edodes). J Appl Biol Chem, 46, 229-234

16. Kwon YM, Kim DH (2002) Effects of sea tangle and chitosan on the physicochemical properties of traditional Kochujang. J Korean Soc Food Sci Nutr, 31, 977-985

17. Han JS (2004) Preparation of mixed beverages for breakfast made primarily with the hydrolysate of sweet potato and its quality characteristics. Korean J Food Cook Sci, 20, 271-278

18. Jeong BC, Ahn YS, Chung MN, Lee JS, Oh YH (2002) Current status and prospect of quality evaluation in sweet potato. Korean J Crop Sci, 47, 124-134
19. Oh HE, Hong JS (2008) Quality characteristics of Sulgidduk added fresh sweet potato. Korean J Food Cook Sci, 24, 501-510

20. Fuwa HA (1954) A new method for microdetermination of amylase activity by the use of amylose as the substrate. J Biochem, 41, 583-603

21. Anson ML (1938) The estimation of pepsin, trypsin, papain and cathepsin with hemoglobin. J Gen Physiol, 22, 79-89

22. Official Methods of Miso Analysis (1968) Institute of Miso Technologists, Tokyo, Japan, p 1-34

23. James MJ (2000) Modern Food Microbiology. 6th ed, APAC, Las Vegas, NV, USA, p 45-47 